\title{
Sustainable Development around Small Scale Mining Areas by the Development of Micro Hydro Power: Application Cases in Cameroon
}

\author{
Fanyep Nana Antoine1, Gubong Takam Charles Bertrand1, \\ Kengne Signe Elie Bertrand ${ }^{12}{ }^{*}$, Claudio J. C. Blanco ${ }^{3}$ \\ ${ }^{1}$ Laboratory of Energy Research in Institute for Geological and Mining Research, Yaoundé, Cameroon \\ ${ }^{2}$ National Advanced School of Engineering, University of Yaoundé1, Yaoundé, Cameroon \\ ${ }^{3}$ College of Sanitary Environmental Engineering, FAESA/ITEC/UFPA, Belémx, Brasil \\ Email: *kengne82@yahoo.fr
}

How to cite this paper: Antoine, F.N., Bertrand, G.T.C., Bertrand, K.S. E. and Blanco, C.J.C. (2020) Sustainable Development around Small Scale Mining Areas by the Development of Micro Hydro Power: Application Cases in Cameroon. Journal of Power and Energy Engineering, 8, 36-48. https://doi.org/10.4236/jpee.2020.83003

Received: January 20, 2020

Accepted: March 27, 2020

Published: March 30, 2020

Copyright $(2020$ by author(s) and Scientific Research Publishing Inc. This work is licensed under the Creative Commons Attribution International License (CC BY 4.0).

http://creativecommons.org/licenses/by/4.0/ c) (i) Open Access

\begin{abstract}
Of all the precious metals buried in the Cameroonian subsoil, gold is certainly the longest exploited. It has longtime been the subject of artisanal exploitation. In 2014, the monthly national production was estimated at around $170 \mathrm{~kg}$. In these mining areas, people still live in a screaming precariousness of which one of the main causes is often the lack of electricity, because of the distance of these localities to the national electricity network. Cameroon has a great hydroelectric potential, but the access rate to electricity is still very low in isolate or rural areas of this country. The objective of this work is to show that it is possible to efficiently exploit gold in isolated areas and contribute to the sustainable development of these localities through the development of micro hydro power (MHP). The mining community of Tikondi in the East Region of Cameroon is the practical case study for an illustration. The results of this study show that the development of the MHP project can be developed with installed power of $87 \mathrm{~kW}$, where the Banki-Michell turbine is recommended according to the Sulzer-Escher Wyss diagram. The investment cost evaluated at $79,832,775$ FCFA ( 1 Euro $=656$ FCFA). It is a profitable project with a maximum payback period of 8 years. This project can be easily funded by gold mining activity. That Tikondi's MHP can make this village becoming attractive for others activities, improving the quality of education of children (there is not any school and lots of them do not go to school), the building of health centers and the quality of life in that locality and therefore contribute to their sustainable development too.
\end{abstract}

\section{Keywords}

Micro Hydro Power, Mining Areas, Sustainable Development 


\section{Introduction}

Cameroon has a very strong mining potential in general and gold in particular. For decades, alluvial gold has been exploited at the artisanal and semi-mechanized scale along rivers. Several localities in the Eastern Region of Cameroon have gold-rich soils with average concentrations often between $0.7 \mathrm{~g} / \mathrm{m}^{3}-1.5 \mathrm{~g} / \mathrm{m}^{3}$. In these areas, people have been living on the search for gold since the $19^{\text {th }}$ century using very light tools such as shovels, picks and sieves, etc. Despite the advantages offered by this activated, supposed to improve the quality of life of the populations, we note with bitterness that the people still live there in a screaming level of precariousness. One of the causes of this precariousness is often the lack of electricity due to the distance of these localities from the national electricity grid. Yet without electricity, it has been proven that an area cannot develop sustainably [1].

This artisanal mining of gold was doing very often along the rivers which include waterfalls favorable for the development of the MHP for the purpose of needs of electric energy in these small localities. But the little electrical energy used in these sites is usually generated by generators using oil. This is not part of a sustainable development perspective.

In Cameroon, the access to electricity in Cameroon was around 49\% in 2012. This rate is about $23 \%$ in rural areas. The energy system is dominated by wood combustible and waste which constitutes a consumption of $77 \%$ (with more than 95\% used for meal cooking), followed by fossils energy which constitutes $17.3 \%$ and lastly by hydropower constituting $4.9 \%$. The main source of electricity generation is from hydro (96\%) and a very little fraction from oil (4\%) [2] [3] [4].

Let's remind that the MHP is a renewable energy plant which has many advantages over the same size of wind and solar renewable energy plants. It has a high efficiency (up to $90 \% \mathrm{~s}$ ), high capacity factor (up to $60 \%$ ) and slow rate of change (due to the water flow varies gradually from time to time) [4].

The objective of this work is to show that it is possible not only to efficiently exploit the gold in isolated area, but also by contributing to the sustainable development of these localities through the MHP development. The mining community of Tikondi in the eastern region of Cameroon is presented as a practical case study for an illustration of this approach.

\section{Mining Context and Energy Problem in Cameroon}

One of the objectives set out in the Growth and Jobs Strategy Paper (GESP) is to reduce underemployment from $75.8 \%$ to less than $50 \%$ in 2020 . On these points, Cameroon can count on its impressive mining potential, a real factor for creating jobs. Of all the precious metals buried in the Cameroonian subsoil, gold is certainly the most important and the longest exploited, because according to the Directorate of Mines and Geology, the first exploitation of gold dates from 1934. It has for a long time been the subject of artisanal exploitation. Nearly 140 gold 
targets are identified in Cameroon. According to the Framework for Support and Promotion of Mining Crafts (CAPAM), the majority of these targets are located in the Eastern Region. In 2014, the estimate of the monthly national production is $170 \mathrm{~kg}$, which $64 \%$ came from the east region. With the CAPAM, the State manages to take about $15 \%$ of exploitation from the companies of artisanal exploitation, to channel $14.1 \mathrm{~kg}$ in the formal circuit [1].

Despite the evolution of several legal and institutional reforms governing the mining sector since 2001, the fact remains that the exploitation of gold remained a semi-mechanized artisanal activity. Several exploration licenses have been issued by the ministry in charge of mines and several research works are carried out until today. But no industrial exploitation license has been issued. During our visits to the gold mining sites, we noticed that almost all the electrical energy used is usually generated by the oil generators. In addition, houses are built with temporary materials, schools are very far away, and there is not any health center. In short, the surrounding populations have no electricity and are still living in extreme precariousness.

A contribution to the sustainable development of these localities is the provision of electricity from renewable sources to the population, and more precisely through the development of the MHP, whose advantages in the production of electricity for isolated sites are proven, with the large network of small rivers that make up the country's watersheds. Recall that Cameroon has one of the greatest potentials in MHP in Africa south of the Sahara that is untapped. A study carried out on the exploited and exploitable potentials of the MHP of some of these countries enabled us to draw up. Figure 1 shows this situation [5] [6].

Figure 1 shows that the other countries are already making efforts in MHP while in Cameroon exploitation is virtually zero despite its privileged position in the field.

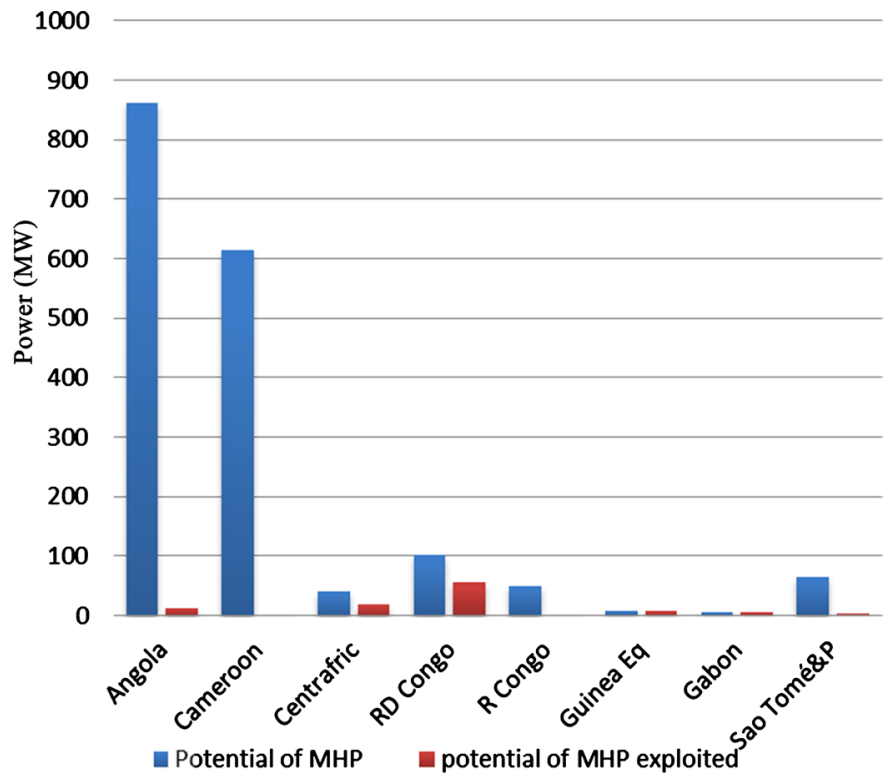

Figure 1. Potential exploitable and exploited in some African countries. 
It is clear that the development of the MHP in the mining zones in Cameroon would allow the incentive to diversify income-generating activities (agriculture, livestock, etc.), the improvement of the conditions of studies of young people (schooling rate), and the improvement of the quality of life in these localities and consequently a vision placed in a perspective of sustainable development.

\section{Materials and Methods}

There is not any universal classification of hydro power plant according to the installed power. In the Cameroon case and in this study, we will consider that a small scale hydropower system is called micro hydro, which can generate power up to $1 \mathrm{MW}[7]$.

\subsection{Study Site and Materials}

The practical case that we studied from end to end is that of Tikondi. The main activity of this village is the exploitation of gold by a company (optimum mining) which makes the semi-mechanized and the populations who make the artisanal exploitation. Figure 2(a) shows a gold digger team at work and Figure 2(b) a pace of dwellings.

The electricity used here is produced only by small generators. The oil supply constraints for their operation regularly cause the passage of several days and weeks without electricity. In addition, it is not an encouraging solution for the reasons mentioned above.

The Tikondi auriferous district is located in the East Region of Cameroon situated $60 \mathrm{~km}$ from Bertoua the regional headquarter. There is a river in that called Koubou River in that district. This river is used for alluvial gold mining activities. The positions of the district and koubou permit are illustrated on the map below in Figure 3(a). The watershed of Koubou is in Kadey Division of the East Region of Cameroon. Located in between $4^{\circ} 54^{\prime} 36^{\prime \prime}$ East, $14^{\circ} 19^{\prime} 51^{\prime \prime}$ North [8]. Koubou has good water supply to be used for MHP.

A Software called Mass_hydro for feasibility studies of MHP developed for local need in Cameroon, electronic laser level with Global Positioning Systems (GPS), questionnaire series, length meters, hydrological data and several other
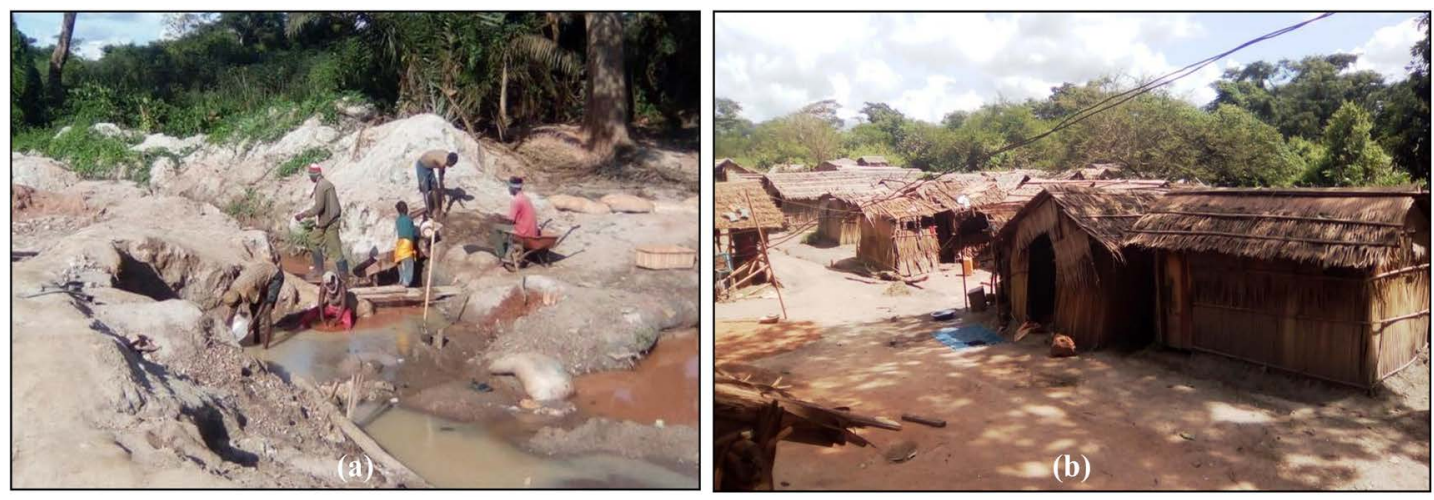

Figure 2. (a) a gold mining team in operation; (b) a pace of housing. 

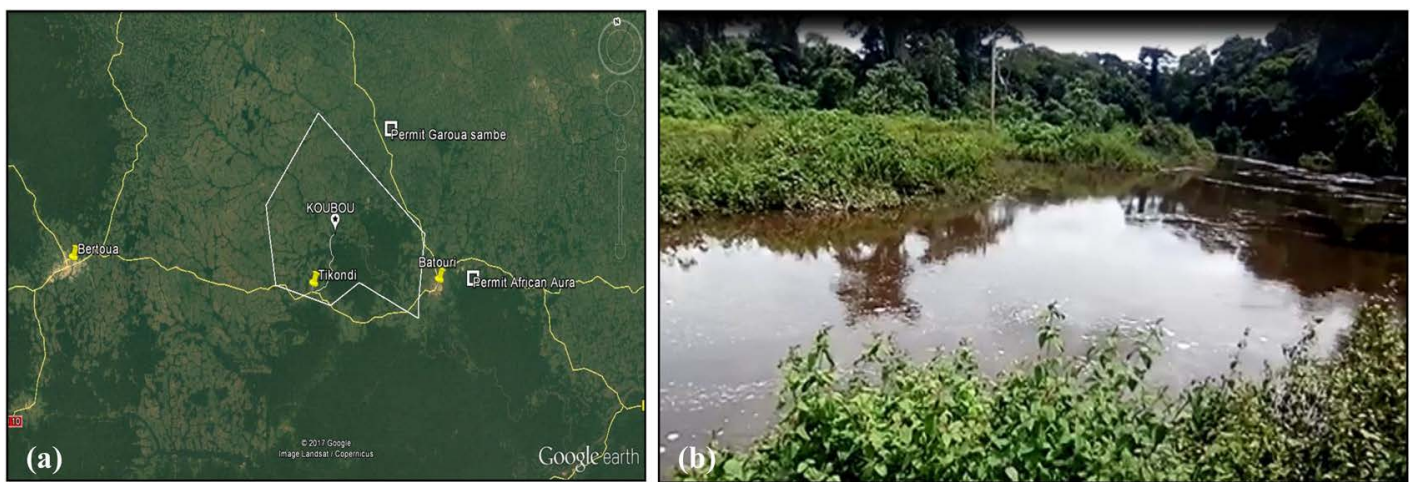

Figure 3. (a) Position of Tikondi; (b) Photograph of the Koubou at the end of the waterfall.

documents were used.

\subsection{Methods}

A Methodology of the feasibility studies of projects of MHP in Cameroon proposed during another research about a MHPP in the West Region, and published in Energy Procedia were used [5] [9]. That methodology gives lots of main steps as following.

\subsubsection{Site Recognition and Topographic Analysis}

During the survey, lots of recognitions visits were done. The gross waterfall height is the altitude difference between the upstream and downstream water levels of the waterfall. A topographic datum can be measured and confirmed thanks to a map for high falls. The gross fall height was measured on this step using an electronic laser level with a suitable accuracy.

\subsubsection{Electricity Demand in the Locality}

The demand for electrical power is based on the number of inhabitants and their activities. The population demand at the end of the maturity is determined by the following formula [5]:

$$
D_{n}=\frac{D_{m} P_{0}(1+\alpha)^{n}}{m}
$$

$D_{n}$ : Population demand in $\mathrm{kW}, n$ : Project duration, $D_{m}$ : Needs per household in $\mathrm{kW}, P_{o}$ : current population, $\alpha$ : annual growth rate of the population and $m$ : average number of persons per household.

\subsubsection{The Equipment Discharge and Installed Power}

For the evaluation, if data about discharge are not available, it will be possible to use a rainfall-runoff model. In case of Cameroon there is a rainfall-runoff model developed and proposed by local experts for equatorial region. This model was developed based on an artificial neural network method. It allows simulating some discharge on waterfall of one year from rainfall data [10]. Then, the next step is to plot the curve of the classified discharges [11]. After that, the power generated from hydraulic turbines could be determined using the following formula: 


$$
P=\eta \cdot \rho \cdot g \cdot Q \cdot H
$$

where $P$ is installed power of plant in $\mathrm{kW}, H$ is net head of water in meter, $Q$ is discharged in $\mathrm{m}^{3} / \mathrm{s}, g$ is gravity acceleration constant $\left(=9.81 \mathrm{~m} / \mathrm{s}^{2}\right)$ and $\eta$ is turbine efficiency (=80\% - 90\%) [5] [7].

\subsubsection{Design and Choice of Technical Components of MHP}

The main technical components of MHP are: The Weir, The water intake, the feeder canal the fore bay, the penstock and power house dimensions [6]. There lots of software as RETSCREEN which can help to design these technical components. In case of Cameroon, new efficiency software called Mass_Hydro was developed with success. This software allows taking into account local advantages and constraints [12].

\subsubsection{Turbine Choice}

The choice of the turbine and generator is made as a function of the nominal flow rate $Q_{n}$ and the net head $H_{n}$ according to the Sulzer-Escher Wyss diagram [4], as shown in the following Figure 4.

\subsubsection{Economic Analysis}

To set up a MHP, the costs of different elements depend on environment constraints and vary from a site to another. Local materials are much recommended to reduce costs. A MHP can usually operate around $60 \%$ to $80 \%$ of time per year, and the operating costs represent $30 \%$ of the cash-flow [5].

The net actual value $(N A V)$ of the project is given by the following formula:

$$
N A V=\sum_{i=1}^{N} \frac{C F_{i}-C_{i}}{(1+x)^{i}}-I_{0}
$$

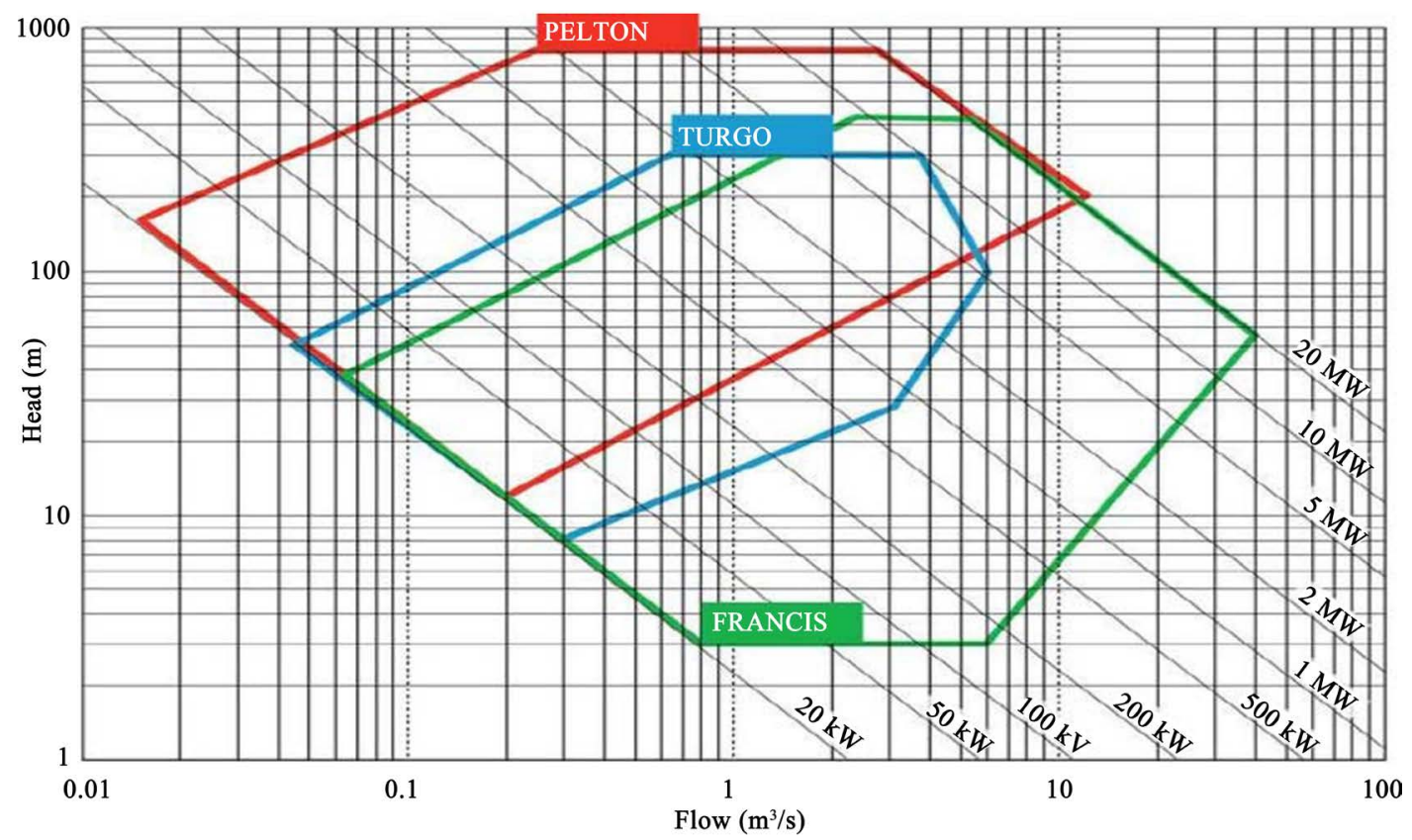

Figure 4. Turbine selection. 
where the initial investment cost is $I_{0}$; discount rate is " $x$ "; for years $1,2, \ldots, N$, Cash-flows and Operating costs can be respectively represented by: $F_{1}, F_{2}, \ldots, F_{N}$; $C_{1}, C_{2}, \cdots, C_{N}$; The net actual value (NAV) of the project is given by the following equation:

The project is profitable if NAV $\geq 0$.

\section{Results and Discussions}

\subsection{Results}

\subsubsection{The Gross Height and the Discharges}

The gross fall height was measured on this step using an electronic laser level with a suitable accuracy. After many measurements, the gross head obtained is $2.9 \mathrm{~m}$. Since that river does not have hydrological data, we have used a rainfall-runoff model proposed for equatorial area in Cameroon for the design of MHP [8]. Using average daily rainfall data of the year 2015 in the watershed concerned, collected from the meteorological office in the Kadey division of ministry of transport, we simulated average daily flows rate which allows plotting the flow duration curve (Figure 5).

\subsubsection{The Need for Electricity in the Locality}

The inhabitants sometimes use generators based on fossil fuel sources that not only, have higher production costs but are also highly polluting. Nearly, 150 houses were recorded. There are on average 5 peoples per household. The average annual rate of population growth in Cameroon was estimated at $3 \%$ at 2010 [13]. Considering the fact that it is a mining area, potentially the need for electricity is more important there than in other simple regions. Then, the power requirement is, according to equation (1) and integrated in our software, $\mathrm{Bn}=$ $162 \mathrm{~kW}$. But the real demand in the village is more important globally. An interconnection to the national network allows us to look this demand more increased in a near future.

\subsubsection{Population Participation}

The local population must play a central role in the decisions to be taken in the

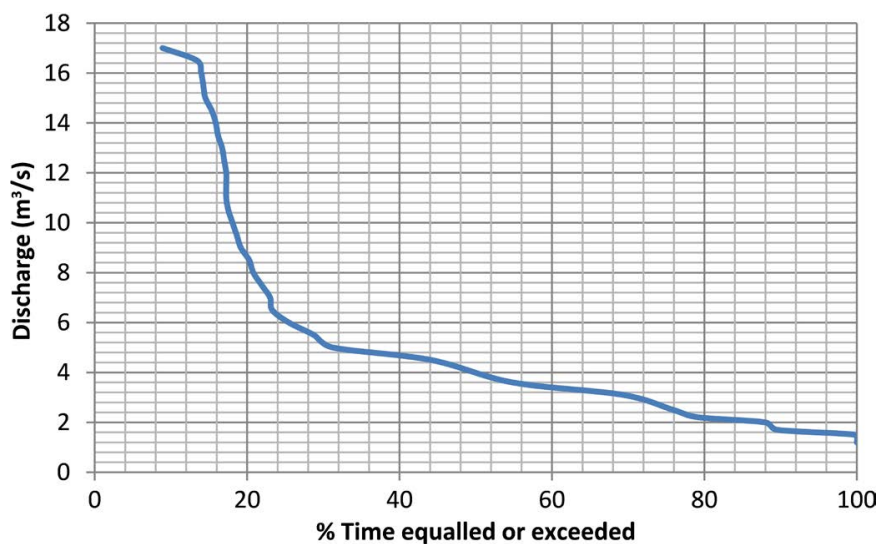

Figure 5. Flow duration curve of Koubou. 
development and implementation of the MHP. A local committee to participate in the project and to manage the operation will be set up. As recommended in a recent study concerning the development of MHP in Cameroon [4], this committee will have skills such as: religious, agents of the municipality, farmers, breeders and fishermen, small traders and other representatives of the community according to cultural varieties... etc.

\subsubsection{Electrical Power and Energy}

Our software proposed the flow rate of equipment equals $3.6 \mathrm{~m}^{3} / \mathrm{s}$ corresponding to the $70 \%$ of time equaled or exceeded per year in the flow duration curve and the installed power is $87 \mathrm{~kW}$. This is done applying formula (2). $\mathrm{P}=87 \mathrm{~kW}$. So the producible or the annual Energy is:

$$
P_{E}=87 \times 8760=762,120 \mathrm{kWh}
$$

\subsubsection{The Choice of the Technical Components of the Installation}

Characteristics of technical components for that MHP are proposed by our software Mass_hydro. The interface of results presented trough that software can be seen in the following screen [12] (Figure 6).

- The feeding canal: The section is $1.308 \mathrm{~m}^{2}$ corresponding to a diameter $\approx 1.2$ $\mathrm{m}$;

- The fore bay: A section of fore bay proposed is $7.2 \mathrm{~m}^{2}$;

- The penstock: The length of the penstock can be around $10 \mathrm{~m}$. Then for the PVC material, $\mathrm{D}_{\mathrm{p}}=0.842 \mathrm{~m}$. The diameter of the pipe of $0.80 \mathrm{~m}$ available on the market can be considered. Then the minimum thickness of penstock $t_{p}=$ $2.5 \mathrm{~mm}$;

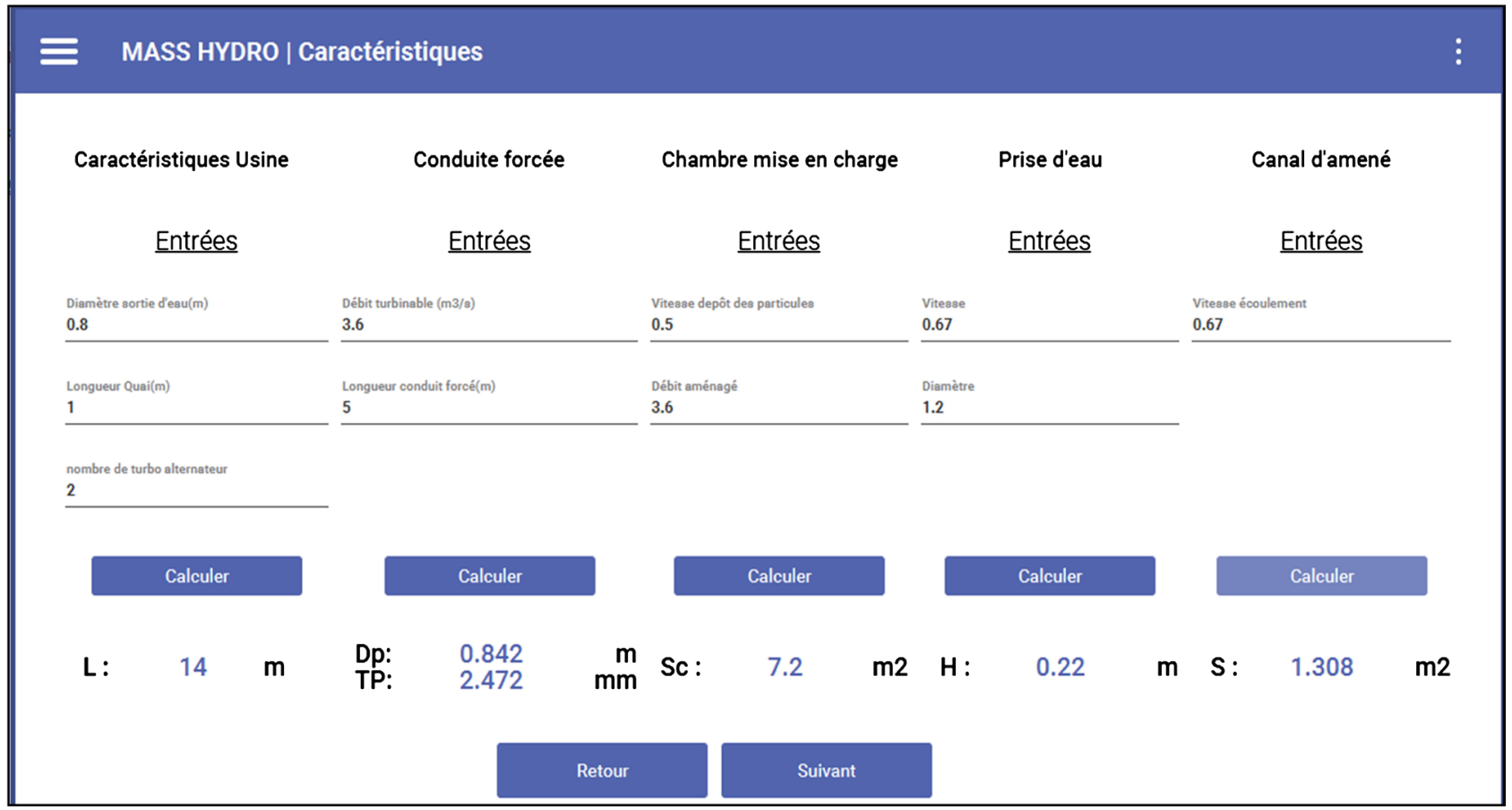

Figure 6. Results of technical components. 
- Power house: The length is $\mathrm{L}=14 \mathrm{~m}$;

- The turbine and generator: According to the Sulzer-Escher Wyss diagram the corresponding turbine is Kaplan turbine. The nominal power of the turbine is $87 \mathrm{~kW}$. A generator synchronous of frequency $50 \mathrm{~Hz}$;

The technical characteristics of that MHP projection, obtained from our study, are summarized in the following (Table 1).

For the exploitation of the MHP of Koubou in Tikondi, that synoptic is proposed in Figure 7.

\subsubsection{The Legal and Regulatory Framework of the Tikondi MHP}

According to the law $n^{\circ} 022 / 2011$ [14], for the MHP of Koubou (Tikondi), whose installed capacity is $87 \mathrm{~kW}$, the legal regime is the authorization and the competent institution is the Electricity Sector Regulatory Board (ARSEL). Also, the generation especially from hydroelectric plants with an installed capacity equals or less than $5 \mathrm{MW}$, no special requirements for tender notices or advertisement shall be imposed. An environmental management plan is required as part of this project.

Table 1. Technical data of the project.

\begin{tabular}{|c|c|}
\hline Sizes & Values \\
\hline \multicolumn{2}{|l|}{ Site characteristics } \\
\hline Gross head & $2.9 \mathrm{~m}$ \\
\hline Mean flow rate & $10.2 \mathrm{~m}^{3} / \mathrm{s}$ \\
\hline \multicolumn{2}{|l|}{ Derivation elements } \\
\hline Feeding canal & $\Phi \approx 1.2 \mathrm{~m}$ \\
\hline Section of fore bay & $7.2 \mathrm{~m}^{2}$ \\
\hline Penstock & $\mathrm{L} \approx 10 \mathrm{~m}, \Phi \approx 0.8 \mathrm{~m} ; \mathrm{t}_{\mathrm{p}}=2.5 \mathrm{~mm}$ \\
\hline \multicolumn{2}{|l|}{ Power house } \\
\hline \multicolumn{2}{|l|}{ Turbine } \\
\hline Type & Kaplan \\
\hline Rotation speed & $375 \mathrm{tr} / \mathrm{min}$ \\
\hline Net head & $2.9 \mathrm{~m}$ \\
\hline Nominal flow rate & $3.6 \mathrm{~m}^{3} / \mathrm{s}$ \\
\hline Nominal power & $87 \mathrm{~kW}$ \\
\hline \multicolumn{2}{|l|}{ Alternator } \\
\hline Type & Synchronal \\
\hline Tension & $380 / 220 \mathrm{~V}$ \\
\hline Frequency & $50 \mathrm{~Hz}$ \\
\hline \multicolumn{2}{|c|}{ Interconnection/distribution } \\
\hline Type of grid & Isolate \\
\hline \multicolumn{2}{|c|}{ Production of electricity } \\
\hline Producible & $762 \mathrm{MWh}$ \\
\hline
\end{tabular}




\subsubsection{Economic Analysis}

\section{- Investment cost}

A recent other assessment done in the other studies concerning the local blacksmith activity gives lots of orientations [5] [15]. The investment cost of MHP varies from a site to another. The following Table 2 shows the cost investment estimation of MHP of Koubou.

\section{- Operating forecasts}

In Cameroon, the prize of electricity in social range is 50 FCFA per kWh [5]. In that locality, which is a rural area, the consumption of each household will be in social range. The producible is equal to $762 \mathrm{MWh}$. Let's consider $70 \%$ as the utilization rate of the MHP for our evaluation. Then, the annual Cash-flow is $\mathrm{CF}=26,674,200$ FCFA.

\section{- Operating expenses}

There are local blacksmiths who were manufacturing micro turbines and some spare parts for MHP in the West Region of Cameroon [15]. Then, maintenance will be at a low cost. In that case, let's consider a running cost of $35 \%$ of the cash-flow. The rate of inflation in Cameroon in 2016 was about 3\%. The discount rate in Cameroon is about $12.5 \%$ [7].

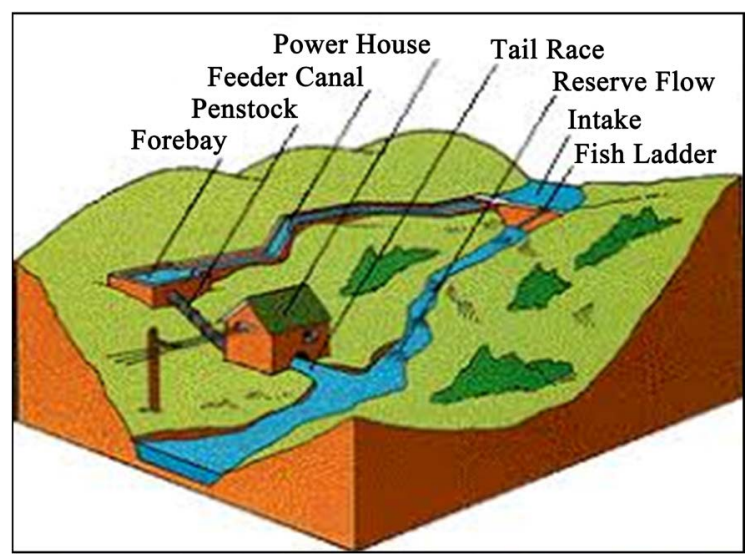

Figure 7. Synoptic diagram of the Koubou MHP.

Table 2. The MHPP investment budget in FCFA.

\begin{tabular}{ccc}
\hline $\mathbf{N}^{\bullet}$ & Component of the MHPP & Total Price (FCFA) \\
\hline 1 & Civil engineering works: Total $1=\mathrm{T}_{1}$ & $39,670,250$ \\
2 & Metal Construction: Total 2 $=\mathrm{T}_{2}$ & $2,430,000$ \\
3 & Turbo-generator group: Total 3 $=\mathrm{T}_{3}$ & $12,675,000$ \\
4 & Equipment for transmission and supply of electricity Total 4 $=\mathrm{T}_{4}$ & $10,800,000$ \\
& Others cost (administration and legal fees): Total 5 $=\mathrm{T}_{5}$ & $7,000,000$ \\
& Total $=\mathrm{T}_{1}+\mathrm{T}_{2}+\mathrm{T}_{3}+\mathrm{T}_{4}+\mathrm{T}_{5}$ & $72,575,250$ \\
Contingencies 10\% $=\mathrm{I}$ & $7,257,525$ \\
& Grand Total & $79,832,775$
\end{tabular}

1 Euro $=656$ FCFA. 


\section{- Estimated profitability}

- Net present value NAV

Considering all the information about the operating cost, if the deadline of project is 20 years, then the NPV of that project is equal to: $\mathrm{NAV}=32,685,938$ FCFA.

Since the net present value is positive. So, the project is profitable with the hypothesis took in account.

\section{- The project payback period (PBP)}

The calculation of the payback period is: $\mathrm{PBP} \approx 7$ years +3 months.

\subsection{Discussion}

In that mining area, as in all other alluvial gold regions, the population mainly needs electricity for lighting, the supply of radios and televisions, the charge of telephones and some transformation and conservation of agricultural products (maize, vegetable, cassava, ...). Then population need cannot be entirely satisfied only by this the Tikondi's MHP, in a long term. But, at least for the five next years after the implementation of that project, the population will not have any problems with electricity. Considering Lomé and Katmandou conferences in 1979 had presented the possibility to feed around one hundred households (in rural area) with $30 \mathrm{~kW}$ [7] [16]. Considering also the fact that energy produced from hydro power is renewable, the MHP of Tikondi can make this village becoming attractive for others activities, improve the building of schools and the quality of education of children (there is not any school there and lots of them do not go to school), the building of health centers, the quality of life of population in that mining village and therefore contribute to their sustainable development too. But, the lack of an effective strategy to apply, collect and manage its funding can be a constraint. There is also a possibility of subsidy from the State according to its vision to promote renewable energy in rural electrification.

\section{Conclusions}

The aim of this work was to put out the contribution to the sustainable development in isolates mining regions through the development of MHP in Cameroon. A case of gold mine site of Tikondi has been particularly studied. The population does not have electricity.

The development of the Koubou MHP in Tikondi will be an example of the contribution of renewable energies to the sustainable development of those mining isolates localities. Considering the hydrological data of the river, the installed power is $87 \mathrm{~kW}$ for an isolated network. A Banki-Michell turbine is recommended for its equipment. The investment cost of this project is $79,832,775$ FCFA. It is a profitable project and the maximum payback period is 8 years. The project is profitable and it is possible to obtain the funding from the alluvial mining gold activities cash-flow. This case could be an example of sustainable development for lots of other alluvial mining areas. 


\section{Conflicts of Interest}

The authors declare no conflicts of interest regarding the publication of this paper.

\section{References}

[1] Civil Cabinet of the Presidency of Republic of Cameroon (2016) The Time of Investments in Mines.

[2] Kengne Signe, E.B., Ooumarou, H. and Nganhou, J. (2016) Modeling of Characteristics of Wind by Weibull Distribution and Estimation of Wind Energy in Douala, Littoral Region of Cameroon. The International Journal of Innovative Research in Science, Engineering and Technology, 5, 6601-6608. https://doi.org/10.15680/IJIRSET.2016.0505001

[3] Kengne Signe, E.B., Kanmogne, A., Emmanuel, G.D. and Meva'a, L. (2019) Comparison of Seven Numerical Methods for Determining Weibull Parameters of wind for Sustainable Energy in Douala, Cameroon. International Journal of Energy Sector Management, 13, 903-915. https://doi.org/10.1108/IJESM-07-2018-0014

[4] Nasir, A.B. (2014) Design Considerations Micro-Hydro-Electric-Power Plant. Energy Procedia, 50, 19-29. https://doi.org/10.1016/j.egypro.2014.06.003

[5] Kengne Signe, E.B., Oumarou, H. and Nganhou, J. (2017) Methodology of Feasibility Studies of Micro-Hydro Power Plants in Cameroon: Case of the Micro-Hydro of KEMKEN. Energy Procedia, 119, 17-28. https://doi.org/10.1016/j.egypro.2017.07.042

[6] Tekounegning (2010) Feasibility Study of de MHPP in the West Region of Cameroon. Ph.D. Thesis, University of Dschang, Yaoundé.

[7] Kengne Signe, E.B., Hamandjoda, O., Nganhou, J. and Wegang, L. (2017) Technical and Economic Feasibility Studies of a Micro Hydropower Plant in Cameroon for a Sustainable Development. Journal of Power and Energy Engineering, 5, 64-73. https://doi.org/10.4236/jpee.2017.59006

[8] http://fr.getamap.net/cartes/cameroon/cameroon_(general)/_tikondii/

[9] Blanco, C., Secretan, Y. and Mesquita, A.L. (2008) Decision Support System for Micro-Hydro Power Plants in the Amazon Region under a Sustainable Development Perspective. Energy for Sustainable Development, 12, 25-33. https://doi.org/10.1016/S0973-0826(08)60435-4

[10] Kengne Signe, E.B., Ooumarou, H., Gubong, T.C. and Fanyep, N.A. (2017) Modeling of Rainfall-Runoff by Artificial Neural Network for Micro Hydro Power Plant: A Case Study in Cameroon. The International Journal of Innovative Research in Science, Engineering and Technology, 6, 15511-15519.

[11] Rapport Centre d'Etudes Techniques Maritimes et Fluviales (2012) Microcentrales hydroélectriques, Note de synthèse', Ministère de l'Ecologie du Développement Durable, des Transport et du Logement en France.

[12] Kengne Signe, E.B., Bachirou, B., Michel, A. and Oumarou, H. (2019) Performance in Feasibility Studies of Micro Hydro Power Plants. New Software Development and Application to the Case of Cameroon. Energy Procedia, 157, 1391-1403. https://doi.org/10.1016/j.egypro.2018.11.304

[13] National Institute of Statistics (INS). Brief Summary of Inflation over the First's Nine Months of the Year 2016. http://www.statistics-cameroon.org

[14] Law n ${ }^{\circ}$ 2011/022. Law Governing the Electricity Sector in Cameroon 2011. 
[15] Kengne Signe, E.B., Tekounegning, Hamandjoda, O. and Nganhou, J. (2015) Local Blacksmith's Activity in the West Region of Cameroon and Their Contribution to the Development of Micro Hydroelectric Power Plants in That Region. African Journal of Environmental Science and Technology, 9, 428-437. https://doi.org/10.5897/AJEST2014.1798

[16] Anonymous (2013) Micro-Hydro Power. http://www.rowan.edu/colleges/engineering/clinics/cleanenergy/rowanuniversitycle anenergyprogram/EnergyEfficiencyAudits/EnergyTechnologyCaseStudies/files/Mic roHydroPower.pdf 